Доктори техн. наук О.Ю. Федоренко, М.I. Рищенко, асп. Л.В. Присяжна (НТУ «ХПІ»)

\title{
ТЕХНОЛОГІЯ, СТРУКТУРА ТА ВЛАСТИВОСТІ КЕРАМІЧНОГО КЛІНКЕРУ ДЛЯ БРУКУВАННЯ ДОРІГ
}

Вступ. Останнім часом серед матеріалів для брукування доріг особливої популярності набувають керамічні клінкерні матеріали. Тільки в Україні обсяги продажу клінкерної кераміки зросли майже втричі. Аналіз динаміки виробництва архітектурно-фасадних виробів свідчить про неухильне зростання частки клінкерних виробів у структурі продукції вітчизняних виробників, що представлена найбільш популярним серед споживачів асортиментом: бруківкою, цеглою та плиткою, які відрізняються формою, розмірами та кольором.

Мостовий клінкер здатний витримувати великі статичні і динамічні навантаження, що дозволяє використовувати цей матеріал для облаштування ділянок i територій 3 інтенсивним транспортним та пішохідним рухом. Клінкерна брущатка використовується також для укріплення насипів, будівництва та оздоблення гідротехнічних огороджень тощо. Функціональність мостового клінкеру обумовлена його фізико-механічними властивостями: високою міцністю, морозостійкістю, витривалістю по відношенню до дії вологи й агресивних хімічних реагентів (розчинів солей, лугів та ін.).

Дана стаття $є$ продовженням розробок співробітників кафедри технології кераміки, вогнетривів, скла та емалей, які спрямовані на розроблення ресурсо- та енергоощадних технологій керамічних будівельних матеріалів 3 використанням нових видів мінеральної сировини.

Постановка завдання досліджень. Розвиток вітчизняного виробництва керамічного клінкеру та наближення його до європейських стандартів потребує підвищення якості та розширення асортименту продукції. У той же час міркування технологічного та економічного характеру вимагають підвищення енергоефективності технологій та зниження собівартості виробів за рахунок використання доступної мінеральної сировини, в т.ч. вторинних ресурсів гірничодобувної промисловості. Тому створення технології мостового клінкеру, орієнтованої на використання широко розповсюдженої неспікливої полімінеральної глинистої сировини, $є$ важливим і актуальним завданням.

Аналіз публікацій, що передували дослідженням. Визначення шляхів інтенсифікації спікання некондиційної глинистої сировини 3 метою отримання клінкерних керамічних виробів привертає увагу багатьох дослідників. Так, у роботах $[1,2]$ наведені результати досліджень кварц-польовошпатових порід як активаторів спікання клінкерних мас. Перспективи використання відходів вуглевидобування (вуглистих аргілітів та алевролітів) у технології дорожнього клінкеру висвітлені в роботі [3]. У роботі [4] розглянуто технологічні аспекти підвищення якості клінкерних керамічних матеріалів, отриманих 3 використанням відходів видобування та переробки гранітів, лужноземельних сієнітів та пегматитів. Результати наших попередніх розробок [5] свідчать про можливість отримання керамічного клінкеру завдяки використанню базальтових туфів, які виконують роль інтенсифікаторів спікання та забезпечують отримання якісного 
керамічного клінкеру на основі неспікливої глинистої сировини при температурі до $1100{ }^{\circ} \mathrm{C}$. Напрямок подальших досліджень визначила необхідність вивчення впливу туфових порід на процеси формування структури та фазового складу отриманих щільноспечених матеріалів 3 високими показниками міцності і морозостійкості.

$\begin{array}{cccr}\text { Методологія } & \text { i } & \text { результати } \\ \text { досліджень. Про } & \text { перспективність }\end{array}$
використання туфів для прискорення спікання керамічних виробів свідчать результати робіт [7, 8]. Для перевірки зроблених припущень щодо здатності активувати спікання та фазоутворення керамічних мас на основі полімінеральної неспікливої сировини здійснено дослідження туфових порід Берестовецького родовища Рівненської області. 3 використанням хімічного (XA), дифференційно-термічного (ДТА) та рентгенофазового (РФА) методів аналізу визначено хіміко-мінеральний склад туфів та досліджено процеси, що супроводжують їх термообробку.

Установлено, що за хімічним складом туфи відповідають натрієвим базальтам сублужного ряду. Сумарний вміст легкоплавких оксидів $\left(\Sigma \mathrm{K}_{2} \mathrm{O}+\mathrm{Na}_{2} \mathrm{O}+\mathrm{Fe}_{2} \mathrm{O}_{3}+\mathrm{FeO}\right)$, який визначає флюсуючу здатність мінеральної сировини, досягає 18 мас. \%. Підвищений вміст у туфах оксидів $\mathrm{CaO}$, $\mathrm{MgO}, \mathrm{MnO}(\Sigma \sim 10 \div 15$ мас. \%) свідчить про можливість їх використання як мінералізуючої добавки, здатної прискорювати процеси фазоутворення при випалі виробів.

Результати ДТА туфів (рис. 1, а) вказують на те, що дегідратація глинистих мінералів, які входять до їх складу, відбувається в широкому температурному інтервалі $130 \div 950{ }^{\circ} \mathrm{C}$. Повне видалення конституційної води спостерігається при $900 \div 950{ }^{\circ} \mathrm{C}$. Наявність водяної пари створює слабовідновлювальне середовище та спричиняє активне утворення кристалічної фази, про що свідчить екзоефект значної інтенсивності 3 максимумом при $990{ }^{\circ} \mathrm{C}$.

Рентгенофазовими дослідженнями (рис. 1, б) встановлено, що фазовий склад дослідних туфів представлений переважно цеолітовими мінералами, монтморилонітом та гідрослюдою. Ці дані доповнюють відомості ДТА щодо порядку перетворень при термообробці туфів, які супроводжуються частковою перебудовою структури породоутворюючих мінералів та формуванням нової кристалічної фази.

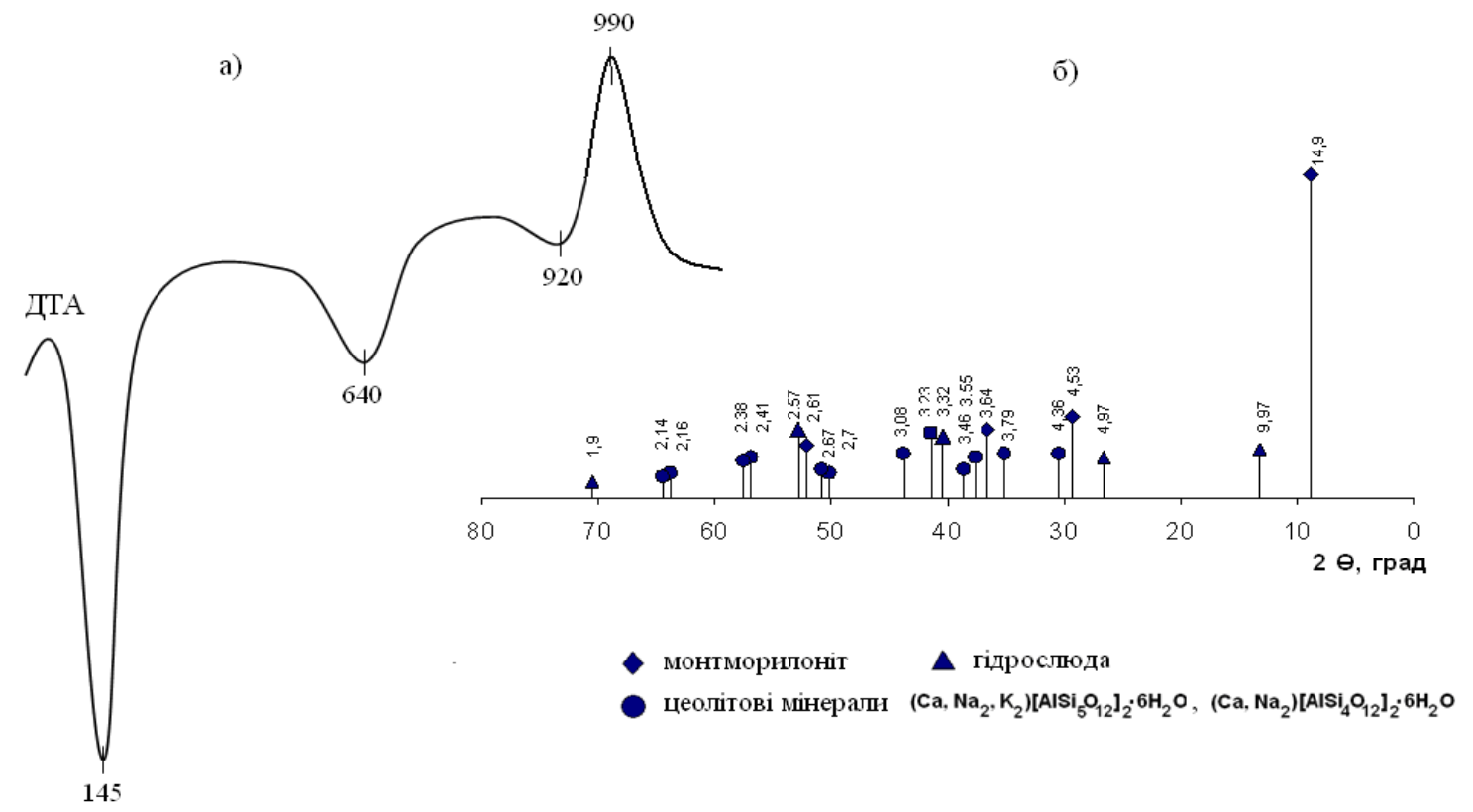

Рис. 1. Крива ДТА (а) та штрих-рентгенограма (б) берестовецького туфу 
Таким чином, комплексними дослідженнями туфових порід підтверджено зроблене нами припущення щодо активності туфів як спікаючої та мінералізуючої добавки до складу мас на основі полімінеральної глинистої сировини, не здатної до спікання при температурі до $1150{ }^{\circ} \mathrm{C}$.

У результаті попередніх досліджень [5] встановлена оптимальна кількість добавки туфів до складу клінкерних мас на основі сумішей глин Верхньосируватського родовища Сумської області. Порівняльна характеристика властивостей продуктів випалу глинистої полімінеральної неспікливої глинистої сировини та мас, що містили 15 мас. \% берестовецьких туфів, подана в таблиці.

Вплив добавки туфу на властивості зразків, випалених при $1100{ }^{\circ} \mathrm{C}$

\begin{tabular}{|l|c|c|c|c|c|c|c|}
\hline \multirow{2}{*}{$\begin{array}{c}\text { Глиниста } \\
\text { складова }\end{array}$} & $\begin{array}{c}\text { Вміст } \\
\text { туфу, } \\
\text { мас. \% }\end{array}$ & $\begin{array}{c}\text { Вогнева } \\
\text { усадка, } \\
\%\end{array}$ & $\begin{array}{c}\text { Водопо- } \\
\text { глинання, } \\
\%\end{array}$ & $\begin{array}{c}\text { Міцність } \\
\text { на стиск, } \\
\text { МПа }\end{array}$ & $\begin{array}{c}\text { Міцність } \\
\text { на згин, } \\
\text { МПа }\end{array}$ & $\begin{array}{c}\text { Зносо- } \\
\text { стійкість, } \\
\text { г/см }\end{array}$ & $\begin{array}{c}\text { Морозо- } \\
\text { стійкість, } \\
\text { цикл }\end{array}$ \\
\hline \multirow{2}{*}{ Суглинок } & - & 10,2 & 7,74 & 23,32 & 2,5 & 0,61 & 76 \\
\cline { 2 - 8 } & 15 & 13,5 & 3,25 & 60,55 & 6,4 & 0,22 & $>300$ \\
\hline \multirow{2}{*}{$\begin{array}{l}\text { Глина } \\
\text { строката }\end{array}$} & - & 10,8 & 8,68 & 27,81 & 3,0 & 0,55 & 70 \\
\hline Глина & - & 12,9 & 3,50 & 65,20 & 6,9 & 0,18 & $>300$ \\
\cline { 2 - 8 } бура & 15 & 12,5 & 3,71 & 70,82 & 7,2 & 0,17 & $>300$ \\
\hline \multirow{2}{*}{$\begin{array}{l}\text { Глина } \\
\text { сіра }\end{array}$} & - & 9,0 & 9,50 & 26,47 & 1,8 & 0,58 & 58 \\
\cline { 2 - 8 } & 15 & 11,5 & 4,00 & 63,54 & 6,7 & 0,20 & $>300$ \\
\hline
\end{tabular}

Отримані дані свідчать про ефективність використання базальтового туфу як інтенсифікатора спікання в технології керамічних клінкерних виробів.

Як відомо, за призначенням клінкерні керамічні вироби поділяють на стінові, тротуарні та дорожні [6]. Залежно від межі міцності на стиск та характеру розташування порожнин продукція поділяється на марки: стінові вироби 3 горизонтальним розміщенням порожнин (M100, М125, М150); стінові вироби 3 вертикальним розміщенням порожнин (M200, M250, М300); повнотілі тротуарні вироби (М150, М175, М200, М250, М300) та повнотілі дорожні вироби (М300, М400, M500, М600, M700, М1000). При цьому водопоглинання стінових i тротуарних виробів, а також дорожніх виробів марок M400, М500 має не перевищувати 6 мас. \%. $\mathrm{y}$ той же час водопоглинання дорожнього клінкеру марок М600, М700 має бути не більше 4 мас.\%; а виробів марки М1000 не більше 2 мас. \%. Відповідно за морозостійкістю клінкерні вироби розташовуються в такий ряд: стінові (F100; F150; F200); тротуарні (F200; F250; F300); дорожні (F300 і більше).

Результати досліджень основних властивостей отриманих клінкерних матеріалів (див. таблицю) свідчать про те, що введення 15 мас. \% базальтового туфу до складу мас дозволяє отримати при температурі $\quad 1100{ }^{\circ} \mathrm{C}$ щільноспечені матеріали 3 водопоглинанням $\mathrm{W} \leq 4 \%$, зносостійкістю $\mathrm{D}=0,17 \div 0,22 \Gamma / \mathrm{cm}^{2}$, міцністю на стиск $\sigma_{\text {ст }}=60 \div 70 \mathrm{MПа,} \mathrm{міцністю} \mathrm{на}$ згин $\sigma_{3 г}=6,4 \div 7,2$ та високою морозостійкістю (F> 300 циклів).

Дослідження структури та фазового складу отриманих матеріалів здійснювали 3 використанням електронномікроскопічного 
та рентгенофазового методів аналізу (рис. 2).

Установлено, що високий рівень спікання обумовлений утворенням значної кількості розплаву $(\sim 25 \div 28$ об. \%), який ущільнює матеріал, залишаючи лише замкнуті пори малого розміру ( $3 \div 7$ мкм). Утворення таких кристалофаз, як кварц, муліт та авгіт підвищує міцність та зносостійкість клінкеру, а також надає кислотостійкості завдяки цінним властивостям цих фаз: підвищеній щільності, твердості та нерозчинності в розчинах кислот i солей. У свою чергу низька відкрита поруватість матеріалу забезпечує високу морозостійкість клінкеру.

Таким чином, у результаті реалізації експерименту отримано керамічний клінкер марки M600, який за комплексом фізикомеханічних та експлуатаційних властивостей задовольняє вимоги ДСТУ Б В.2.7-245: 2010 до мостового клінкеру [6].

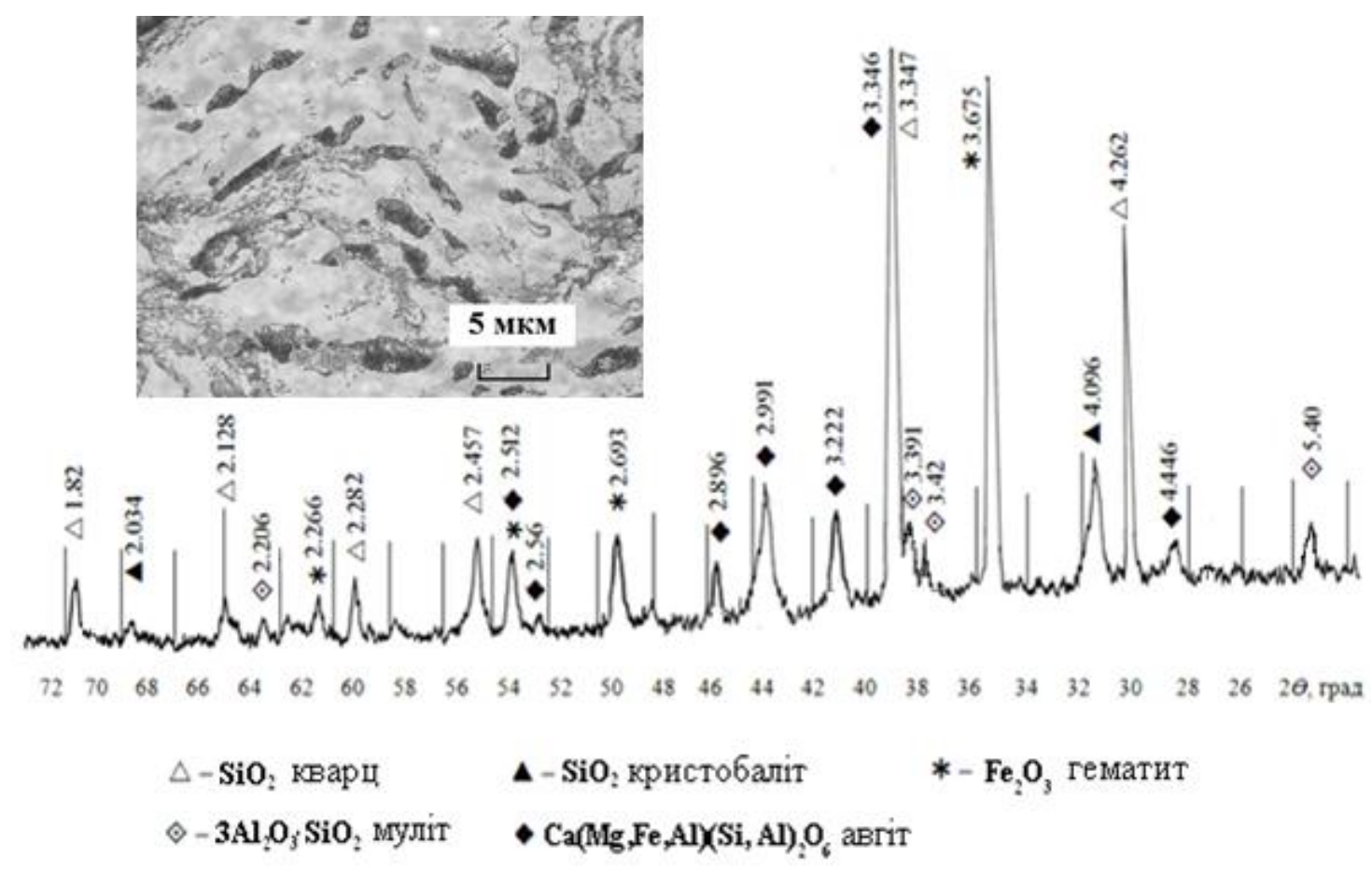

Рис. 2. Структура та фазовий склад мостового керамічного клінкеру

Висновки i рекомендації. $\mathrm{y}$ результаті проведених досліджень підтверджена ефективність використання туфових порід як інтенсифікатора спікання та фазоутворення клінкерних керамічних мac.

Показано можливість отримання мостового клінкеру при використанні різних видів неспікливої полімінеральної глинистої сировини при введенні до складу мас 15 мас. \% базальтових туфів.

Визначено вплив добавки на властивості керамічного клінкеру, які обумовлюють його якісні характеристики.

Встановлено особливості структури та фазового складу отриманих матералів у взаємозв'язку з їх фізико-механічними та експлуатаційними властивостями. 


\section{Список літератури}

1. Огороднік, І.В. Керамічний клінкер для обличкування фасадів та брукування доріг 3 використанням польовошпатвмісної сировини [Текст] / І.В. Огороднік, Т.В. Ходаковська, Н.Д. Дмитренко // Будівельні матеріали, вироби та санітарна техніка. - 2006 . - № 22 - С. 60-67.

2. Массы для клинкерного кирпича на основе сырьевых материалов Донецкого бассейна [Текст] / Е.С. Цыбулько, В.В. Коледа, Е.В. Алексеев, Е.С. Михайлюта // Вісник НТУ «ХПІ»: зб. наук. праць. Тематичний випуск «Хімія, хімічна технологія та екологія». 2009. - № 45. - С. 38-46.

3. Федоренко, О.Ю. Технологія виготовлення клінкерних керамічних виробів на основі відходів вуглевидобування [Текст] / О.Ю. Федоренко // Экология и промышленность. - 2009. - № 1. - С. 46-51.

4. Федоренко, О.Ю. Технологічні аспекти підвищення якості клінкерних керамічних матеріалів [Текст] / О.Ю.Федоренко, М.I. Рищенко, Л.В. Присяжна // Зб. наук. праць ПАТ «УкрНДІВогнетрвів ім. А.С. Бережного». - 2011. - № 111. - С. 199-207.

5. Клінкерні керамічні вироби 3 використанням базальтових туфів [Текст] / О.Ю. Федоренко, М.І. Рищенко, Л.В. Присяжна, А.Г. Токарев // Зб. наук. праць ПАТ «УкрНДІВогнетрвів ім. А.С. Бережного». - 2012. - № 112. - С. 238-243.

6. Вироби керамічні клінкерні. Технічні умови [Текст]: ДСТУ Б В.2.7-245: 2010. [Чинний від 2010-12-16]. - К. : Міністерство регіонального розвитку та будівництва України, 2011. - 31 с. - (Національний стандарт України).

7. Мельничук, В.Г. Туфи Волино-Поділля як новий вид мінеральних ресурсів [Текст] / В.Г. Мельничук, В.В. Матеюк // Проблеми раціонального використання, охорони i відтворення природно-ресурсного потенціалу України. - Чернівці 2000. - С. 133-134.

8. Шильцина, А.Д. Использование кальцитсодержащих туфов для получения облицовочных керамических плиток [Текст] / А.Д. Шильцина, В.И. Верещагин // Известия вузов: сб. науч. трудов. Тематический выпуск «Строительство». - 1999. - № 8. - С. 46-49.

Ключові слова: клінкерні керамічні вироби, мостовий клінкер, структура, міцність, зносостійкість, морозостійкість.

\section{Анотаціï}

Наведено результати розроблення клінкерних керамічних матеріалів 3 високими фізико-механічними властивостями. Досліджена їх структура i фазовий склад у взаємозв'язку 3 основними властивостями. Підтверджена ефективність використання туфових порід для інтенсифікації спікання та фазоутворення полімінеральної глинистої сировини, не здатної до спікання.

Представлены результаты разработки клинкерных керамических материалов с высокими физико-механическими свойствами. Исследованы их структура и фазовый состав во взаимосвязи с основными свойствами. Подтверждена эффективность использования туфовых пород для интенсификации спекания и фазообразования полиминерального неспекающегося глинистого сырья.

The article presents the development results of clinker ceramic materials with high physicmechanical properties. Their structure and phase composition in the relationship with the basic properties are explored. The efficiency of the tuffs breeds use for intensification of sintering and phase formation of multymineral clays, unable to sintering, is confirmed. 